
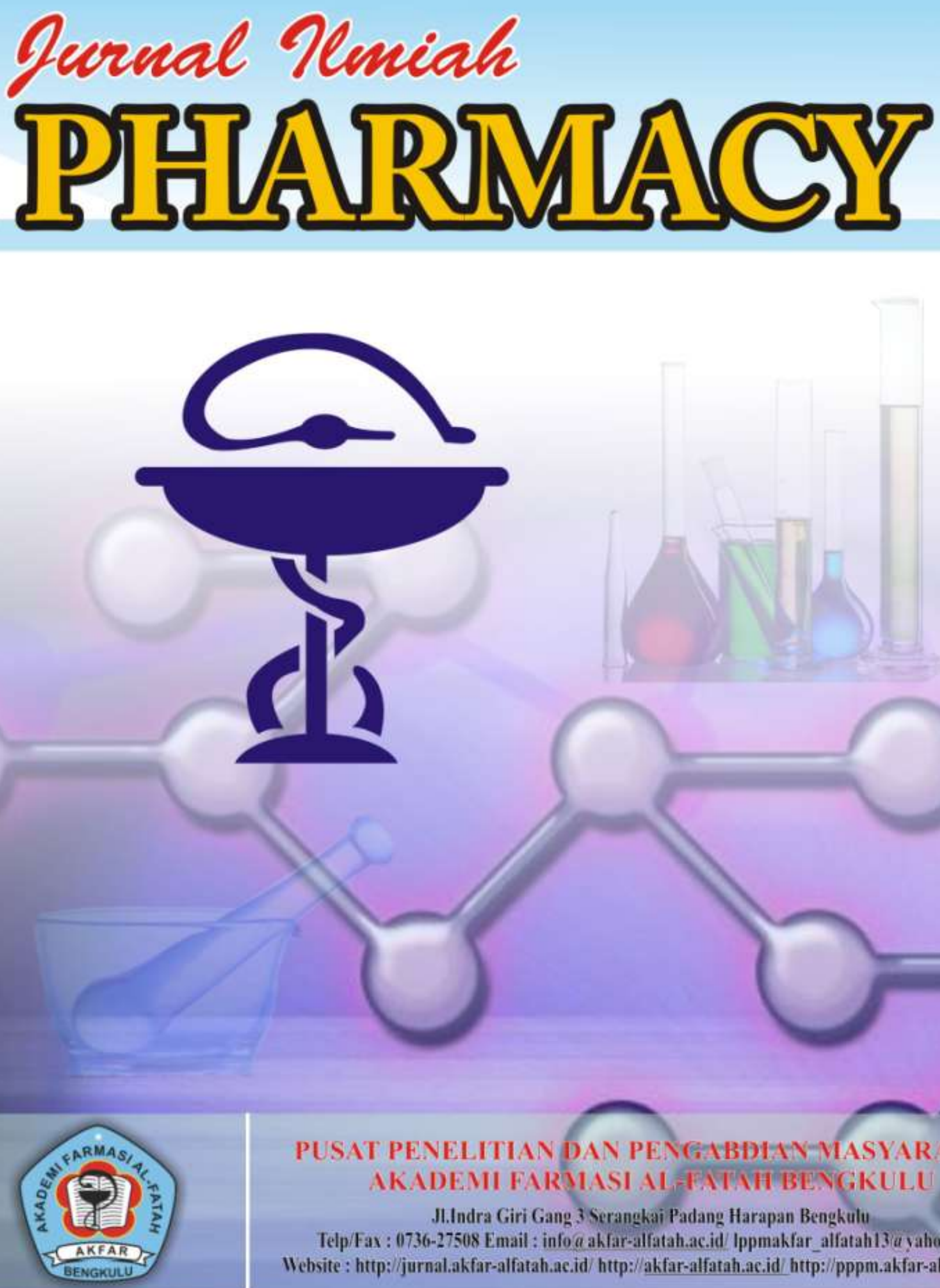

PUSAT PENELITIAN DAN PENGABDIAN-MASYARAKAT AKADEMI FAR MASI AL TAT VII BENGKULU JI.Indra Giri Gang 3 Seranghai Padang Harapan Benghulu Telp/Fax : 1736-27508 Email : info a ahfar-alfatah.ac.id Ippmakfar_alfatah 13 a yahoo.com Website : http:/jurnal.akfar-alfatah.ac.id/ http:/akfar-alfatah.ac.id http://pppm.akfar-alfatah.ac.id 


\section{Vol.7 No.1 Maret 2020}

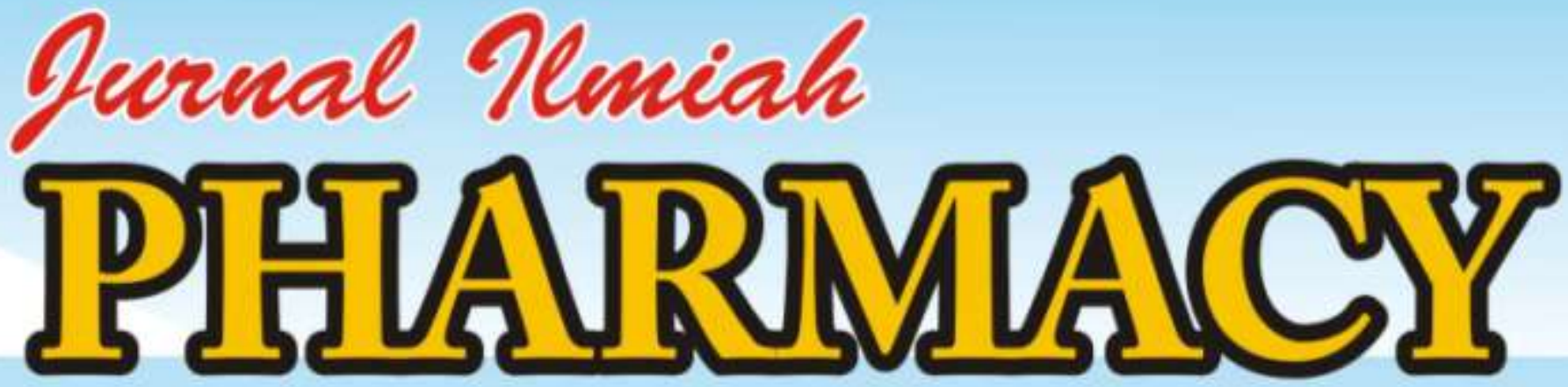

Reviewer

Mitra Bastari

Dr. Arif Setya Budi, M.Si.,Apt (Universitas Ahmad Dahlan, Yogyakarta)

Dr. Moch. Saiful Bachri, S.Si., M.Si.,Apt (Universitas Ahmad Dahlan, Yogyakarta)

Evi Maryanti, M.Si (Universitas Bengkulu, Bengkulu)

M. Adam Ramadhan, M.Sc.,Apt ((Universitas Mulawarman, Kalimantan Timur)

Dr. Awal Isgiyanto, M.Kes (Universitas Bengkulu, Bengkulu)

\section{Penangung Jawab}

Densi Selpia Sopianti, M.Farm.,Apt

\section{Ketua Dewan Redaksi}

Devi Novia, M.Farm.,Apt.

\section{Sekretaris Penyunting}

Febryan Hari Purwanto.M.Kom

Marsidi Amin,S.Kom

\section{Anggota Pelaksana}

Yuska Novi Yanti, M.Farm.,Apt

Setya Enti Rikomah, M.Farm.,Apt

Tri Yanuarto, M.Farm.,Apt

Gina Lestari, M.Farm.,Apt

Betna Dewi, M.Farm., Apt

Luki Damayanti, M.Farm.,Apt

Nurwani Purnama Aji, M.Farm.,Apt

Elly Mulyani,M.Farm.,Apt

Sari Yanti, M.Farm.,Apt

Aina Fatkhil Haque,M.Farm.,Apt

Dewi Winni Fauziah, M.Farm.,Apt

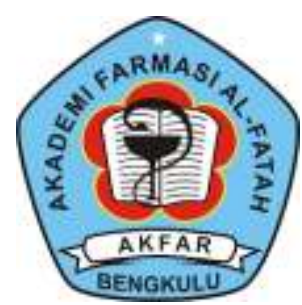

\section{PUSAT PENELITIAN DAN PENGABDIAN MASYARAKAT} AKADEMI FARMASI AL-FATAH BENGKULU

Jl.Indra Giri Gang 3 Serangkai Padang Harapan Bengkulu Telp/Fax : 0736-27508 Email : info@akfar-alfatah.ac.id/lppmakfar_alfatah13@yahoo.com Website : http://jurnal.akfar-alfatah.ac.id/ http://.akfar-alfatah.ac.id/ http://pppm.akfar-alfatah.ac.id 


\section{DAFTAR ISI}

Sensitivitas Bakteri staphylococcus aureus Pada Uji Daya Hambat Ekstrak Kulit Daun Lidah Buaya (Aloe barbadensis Miller)

Hepiyansori ${ }^{1}$, urman $^{2}$, Vera Lusiana ${ }^{3}$

Akademi Analis Kesehatan Harapan Bangsa

Gambaran Tingkat Pengetahuan Masyarakat Tentangdagusibu di Desa Suka Bandung Kecamatan Pino Raya Kabupaten Bengkulu Selatan

Tri Damayanti, Panti Yuniarti Z, Lesmi Ekawati Sera Putri

Akademi Farmasi Al-Fatah Bengkulu

Identifikasi Senyawa Flavonoid Dari Ekstrak Daun merampuyan (Rhodamnia cinerea Jack) Dengan Metode KLT

Densi Selpia Sopianti, Tri Sulasmi

Akademi Farmasi Al-Fatah Bengkulu

Uji Efektivitas Air Perasan Jeruk Nipis (Citrus Limon)Dan Jeruk Lemon(Citrus aurantifolia)Terhadap Mortalitas Kutu Kepala (Pediculus humanus capitis)

Inayah Hayati ${ }^{l}$, Heni Nopitasari ${ }^{2}$

Akademi Analis Kesehatan Harapan Bangsa Bengkulu

Pengukuran Konsentrasi Hemoglobin Menggunakan Metode Cyanmethemoglobin Pada Petugas SPBU di Kota Bengkulu Rini Susanti ${ }^{1}$,Hepiyansori ${ }^{2}$, Rima Gustin ${ }^{3}$

Akademi Analis Kesehatan Harapan Bangsa

Perbandingan Kadar Vitamin C Pada Buah Apel Impor Dan Apel Lokal

Nita Anggreani, Mardiansyah, Rama Gusti Prayenda

Akademi Analis Kesehatan Harapan Bangsa Bengkulu

Pemeriksaan Bilangan Peroksida Pada Minyak Goreng Yang Sudah Dipakai Beberapa Kali Oleh Penjual Gorengan Di Simpang Empat Pagar Dewa Kota Bengkulu

Eka Nurdianty Anwar, Wendi

Akademi Analis Kesehatan Harapan Bangsa Bengkulu

Skrining Fitokimia Metabolit Sekunder Daun Ketepeng Cina Senna alata (L.)Roxb Dengan Metode Kromatografi Lapis Tipis (KLT)

Yuska Noviyanty, Devi Novia, Dayu Nofiyan

Akademi Farmasi Al-Fatah Bengkulu 
Pengaruh Jenis Pelarut Terhadap Kandungan Total Flavonoid Ekstrak Daun Alpukat

(Persea Americana Mill) Secara Spektrofotometri UV - VIS

Herlina $^{1}$, Elly Mulyani ${ }^{1}$

1) Akademi Farmasi Al-Fatah Bengkulu

69-78

Pengaruh Pemberian Infusa Daun Jati (Tectona grandis L.S) Terhadap Waktu Kematian Cacing

Ascaridia galli Sp Secara In Vitro

Devi Novia, Agung Giri Samudra, Camelia ZA

Akademi Farmasi Al-Fatah Bengkulu

Uji Efektifitas Antidiare Ekstrak Etanol Umbi Ganyong (Canna edulis Ker) Terhadap

Mencit Jantan (Mus musculus)

Luky Dharmayanti ,Nurwani Purnama Aji ,Siska Handayani

Akademi Farmasi Yayasan Al-Fatah Bengkulu

89-98

Identifikasi Senyawa Alkaloid Ekstrak N-Heksan Daun SubangSubang (Scaevola Taccada L.)

Nurwani Purnama Aji ${ }^{1)}$, Titin Fitria Ningsih ${ }^{1)}$, Nurfijrin Ramadhani ${ }^{1)}$

${ }^{1)}$ Akademi Farmasi Al-Fatah Bengkulu

99-105

"Formulasi Sabun Padat Dengan Variasi Ekstrak Kulit Buah Kakao (Theobroma cacao L.) dan Virgin Coconut Oil (VCO)” Betna Dewi ${ }^{1}$, M.Arobiq ${ }^{l}$ Aina Fatkhil Haque ${ }^{1}$

${ }^{1}$ Akademi Farmasi Al-Fatah Bengkulu

106-115

Gambaran Penggunaan Obat Malaria Pada Pasien Rawat Jalan Di Puskesmas Penurunan Kota Bengkulu

Setya Enti Rikomah, M.Farm.,Apt, Elmitra, M.Farm.,Apt, Dwi Lyan Pebriza

Akademi Farmasi Al-Fatah Bengkulu

116-122

Identifikasi dan Penetapan Kadar Senyawa Flavonoid Total dari Ekstrak Etanol Daun Biduri (Calotropis gigantea L) dengan Metode Spektrofotometri vis

Elly Mulyani, Herlina, Rendy Setiawan

Akademi Farmasi Al-Fatah Bengkulu

Uji Efektifitas Antidiare Ekstrak Etanol Umbi Ganyong (Canna edulis Ker) Terhadap Mencit Jantan (Mus musculus)

Tri Yanuarto $^{(1)}$, Luky Dharmayanti ${ }^{1)}$, Siska Handayani ${ }^{1)}$

${ }^{1}$ Akademi Farmasi AL-Fatah Bengkulu 
Pengaruh Iklan Obat Di Media Terhadap Perilaku Konsumsi Obat Pada Masayarakat Di Kelurahan Tanah Patah Kota Bengkulu

Gina Lestari ${ }^{1}$, Rukmana Novitasari ${ }^{1}$, Yuska Novi Yanti ${ }^{1}$

Akademi Farmasi Yayasan Al-Fatah Bengkulu

141-148 


\title{
PENGARUH IKLAN OBAT DI MEDIA TERHADAP PERILAKU KONSUMSI OBAT PADA MASAYARAKAT DI KELURAHAN TANAH PATAH KOTA BENGKULU
}

\author{
Gina Lestari $^{1}$, Rukmana Novitasari ${ }^{1}$, Yuska Novi Yanti ${ }^{1}$ \\ 1. Akademi Farmasi Yayasan Al-Fatah Bengkulu \\ Jl.Indragiri, Gg. Tiga Serangkai Padang Harapan Kota Bengkulu \\ Email : ghinafathur@gmail.com
}

\begin{abstract}
ABSTRAK
Iklan merupakan bentuk penyampaian pesan sebagaimana dalam komunikasi tentang produk atau jasa yang di sampaikan lewat media dan ditunjukkan kepada sebagian atau seluruh masyarakat. Iklan obat merupakan salah satu penyebab orang melakukan pengobatan sendiri. Penelitian ini untuk mengetahui pengaruh iklan obat di media terhadap perilaku konsumsi obat pada masyarakat di kelurahan tanah patah Kota Bengkulu. Penelitian dilaksanakan di kelurahan tanah patah kota bengkulu penelitian di mulai dari januari 2016 sampai maret 2016. Populasi pada penelitian ini seluruh warga yang berusia 15 tahun sampai 59 tahun di kelurahan tanah patah. Jumlah sampel yang di ambil sebanyak 100 orang. sampel penelitian ini di ambil dengan cara teknik accidental sampling data di kumpulkan dengan kuisioner yang telah di isi oleh responden. pengetahuan di kelompokkan menjadi dua kelompok yaitu terpengaruh dan tidak terpengaruh. hasil penelitian dari 100 orang responden di dapatkan responden yang terpengaruh iklan obat sebanyak $30 \%$ dengan perilaku konsumsi obat yang kurang baik, responden yang tidak terpengaruh iklan obat $15 \%$ dengan perilaku konsumsi obat yang baik, terdapat pengaruh iklan obat di media terhadap perilaku konsumsi obat pada masyarakat di Kelurahan Tanah Patah Kota Bengkulu. dalam penelitian ini jenis kelamin yang banyak terpengaruh oleh iklan adalah perempuan. dengan hasil uji Chi-Square didapatkan nilai $p$ value $=0,004$.
\end{abstract}

\section{Kata kunci : Pengaruh Iklan ,Iklan ,Perilaku konsumsi obat}

\section{PENDAHULUAN}

Iklan merupakan suatu media untuk menyampaikan informasi kepada masyarakat terhadap suatu produk. Iklan memiliki fungsi menyampaikan informasi, membujuk atau untuk mengingatkan masyarakat terhadap produk obat. Salah satu cara untuk merebut perhatian masyarakat bukan saja iklan sebagai sarana informasi melainkan sebagai sebuah hiburan, yaitu menumbuhkan perasaan gembira bagi siapapun yang melihatnya, sehingga konsumen tertarik untuk membeli. (Kurniawan, 2010).

Pengobatan di Indonesia mencakup tiga sektor yang saling 
berhubungan, yaitu pengobatan rumah tangga (pengobatan sendiri), pengobatan tradisional, dan pengobatan medis profesional. Dalam pengobatan sakit, seseorang dapat memilih satu sampai tiga sumber pengobatan, tetapi tindakan pertama yang paling banyak dilakukan adalah pengobatan sendiri dan sebagian masyarakat pernah mengobati diri sendiri sebelum mengunjungi puskesmas dan dokter. (Notosiswoyo, 2011).

Masalah kesehatan di Indonesia sebagai salah satu negara berkembang menjadi prioritas utama program pemerintah menuju masyarakat yang sehat dan sejahtera. Untuk mencapai tujuan tersebut pembangunan kesehatan bukan hanya menjadi tanggung jawab pemerintah, namun peran serta dan dukungan dari masyarakat serta pihak swasta sangat dibutuhkan, terlebih lagi mengingat akan keterbatasan dari kemampuan pemerintah baik dari sumber dana maupun sumber daya manusia. usia maka semakin rentan terkena penyakit (Notoatmojo, 2007).

Meskipun berbagai upaya telah dilakukan untuk meningkatkan kesadaran masyarakat dalam berperilaku hidup sehat dan bersih, dan pemerataan pelayanan kesehatan, namun ternyata kesehatan tetap menjadi masalah di Indonesia. Salah satu alasannya karena kemajuan teknologi dan perubahan pola hidup masyarakat yang cenderung kurang memperhatikan kesehatan. Hal ini menyebabkan berkembangnya penyakit yang mendorong masyarakat untuk mencari alternatif pengobatan yang efektif secara terapi tetapi juga efisien dalam hal biaya. Berkenaan dengan hal tersebut pengobatan sendiri menjadi alternatif yang diambil oleh masyarakat. (Hilman.web,2011).

\section{METODOLOGI PENELITIAN}

Penelitian ini menggunakan teknik accidental sampling. teknik accidental sampling adalah pengambilan sampel siapa saja yg bisa di jadikan sampel yang kebetulan ada pada saat pengambilan. Kriteria pada sampel yang diambil pada penelitian ini adalah:

\section{a. Kriteria Inklusi}

1. Tercatat sebagai warga kelurahan Tanah Patah Kota Bengkulu

2. Bersedia menjadi responden

3. Tidak sedang sakit

4. Usia 15 sampai 60 tahun

b. Kriteria Inklusi 
1. Tidak berada di tempat saat interview

2. Pindah tempat tinggal, di luar kelurahan Tanah Patah Kota Bengkulu

\section{Usia $<15$ thn}

\section{PENGOLAHAN DATA}

Data masyarakat di ambil dengan menggunakan kuesioner, kemudian data di kumpulkan dan di lakukan pengolahan data dengan menggunakan beberapa tahap yaitu editing (pemeriksaan), coding (Pengodean), processing (memproses data), tabulating (tabulasi data). Setelah data terkumpul dari hasil pengumpulan data lalu di lakukan analisis data.

\section{HASIL DAN PEMBAHASAN}

Hasil dari penelitian ini dengan menggunakan teknik accidental sampling. kuesioner yang di dapatkan selama penelitian dari bulan januari 2016 sampai bulan maret 2016 di kelurahan tanah patah kota bengkulu yaitu di dapat kuesioner sebanyak 100 kuesioner.di dapatkan hampir sebagian responden yang terpengaruh iklan obat sebanyak $30 \%$ dengan perilaku konsumsi obat yang kurang baik dan tidak terpengaruh iklan obat $15 \%$ dengan perilaku konsumsi obat yang baik.

\begin{tabular}{|c|c|c|c|c|c|c|c|c|c|c|}
\hline \multirow[t]{3}{*}{ No } & \multirow{3}{*}{$\begin{array}{l}\text { Pengaruh } \\
\text { iklan obat }\end{array}$} & \multicolumn{6}{|c|}{ Perilaku konsumsi obat } & \multirow{2}{*}{\multicolumn{2}{|c|}{ Total }} & \multirow{3}{*}{$\begin{array}{c}\mathbf{P} \\
\text { Value }\end{array}$} \\
\hline & & \multicolumn{2}{|c|}{ Baik } & \multicolumn{2}{|c|}{ Cukup } & \multicolumn{2}{|c|}{ Kurang } & & & \\
\hline & & $\mathbf{n}$ & $\%$ & $\mathbf{N}$ & $\%$ & $\mathbf{N}$ & $\%$ & $\mathbf{N}$ & $\%$ & \\
\hline 1 & Terpengaruh & 22 & 22 & 24 & 24 & 30 & 30 & 76 & 100 & 0,004 \\
\hline 2 & $\begin{array}{c}\text { Tidak } \\
\text { Terpengaruh }\end{array}$ & 15 & 15 & 1 & 1 & 8 & 8 & 24 & 100 & \\
\hline & Jumlah & 37 & 37 & 25 & 25 & 38 & 38 & 100 & 100 & \\
\hline
\end{tabular}

\section{a. Jenis Kelamin}

Berdasarkan hasil penelitian, distribusi frekuensi Jenis Kelamin menunjukkan bahwa sebanyak 36\% responden yang jenis kelamin lakilaki, 64\% responden yang ber jenis kelamin perempuan. Dengan bertambahnya usia seseorang, maka semakin membutuhkan perawatan tubuh yang lebih intens sebab kondisi fisik sudah semakin melemah, organ tubuhpun sudah berkurang vitalitasnya maka dari itu iklan membuat masyarakat untuk membeli obat semakin bertambah usia maka semakin rentan terkena penyakit (Notoatmojo, 2007).

\section{b. Pendidikan}

Berdasarkan hasil penelitian, distribusi frekuensi pendidikan 
responden menunjukkan bahwa sebanyak $2 \%$ responden pendidikan SD, pendidikan SMP sebanyak $20 \%$ responden, pendidikan SMA sebanyak $70 \%$ responden, dan pendidikan Perguruan Tinggi sebanyak $8 \%$ responden.

Pendidikan adalah suatu usaha untuk mengembangkan kepribadian dan kemampuan di dalam dan di luar sekolah dan berlangsung seumur hidup. Pendidikan mempengaruhi proses belajar, makin tinggi pendidikan seeorang makin mudah orang tersebut untuk menerima informasi. Tingginya Pendidikan seseorang maka orang tersebut akan cenderung untuk mendapatkan informasi, baik dari orang lain maupun dari media massa. Semakin banyak informasi yang masuk semakin banyak pula pengetahuan yang didapat tentang kesehatan (Notoadmojo, 2007).

\section{c. Status Pekerjaan}

Berdasarkan hasil Penelitian yang terjadi pada tabel III, distribusi frekuensi status pekerjaan responden, didapatkan $7 \%$ responden bekerja sebagai PNS/Polri/TNI, 39\% responden bekerja di bidang swasta, $2 \%$ responden bekerja sebagai petani, $17 \%$ responden pedagang, dan $35 \%$ responden bekerja sebagai buruh, sopir, nelayan, dan lainnya.

Pekerjaan seseorang umumnya memiliki dampak yang penting dalam upaya meminimalisasi seseorang dalam terkena penyakit. pekerjaan yang cukup berat umumnya menguras keringat karena lebih banyak menggunakan otot dibadingkan dengan pikiran. pendapatan juga mempengaruhi masyarakat untuk membeli obat di banding berobat, sehingga Menyebabkan rentan terkena penyakit di dukung dengan memiliki pengetahuan yang kurang tentang penyakit dan cara pengobatan. Faktor yang mempengaruhinya adalah stress dalam bekerja dan pola hidup yang tidak sehat, sebagian pendapatan juga dapat mempengarui iklan karena semakin rendah tingkat pendapatan seorang maka semakin rendah perilaku komsumsi obat pada masyarakat, iklan membantu masyarakat dalam memilih obat (Notoadmojo, 2007).

\section{d. Pengaruh Iklan Obat}

Berdasarkan hasil penelitian, distribusi frekuensi pengaruh iklan obat menunjukkan bahwa sebanyak $76 \%$ responden yang terpengaruh iklan obat di media, dan sebanyak $24 \%$ responden yang tidak terpengaruh terhadap iklan obat di media. 
Sebuah iklan produk akan memberikan citra yang selalu memikat orang yang melihatnya. Suatu merek produk akan menarik perhatian orang yang memperhatikan iklan. Masyarakat yang melihat kemudahankemudahan yang ditayangkan sebuah iklan, pada akhirnya tertarik untuk memiliki produk yang diiklankan dengan maksud agar dapat meringankan pekerjaannya (Kurniawan, 2010).

Iklan merupakan salah satu bentuk promosi yang paling dikenal dan paling banyak dibahas orang. Hal ini kemungkinkan karena daya jangkauannya yang luas. Iklan juga menjadi instrument promosi yang sangat penting khususnya bagi perusahaan yang memproduksi barang atau jasa yang ditujukan kepada masyarakat luas (Dimara, 2012).

\section{e. Perilaku Konsumsi Obat}

Berdasarkan hasil Penelitian, distribusi frekuensi perilaku konsumsi obat menunjukkan bahwa sebanyak $37 \%$ responden yang berperilaku konsumsi obat yang baik, sebanyak $25 \%$ responden yang berperilaku konsumsi obat cukup baik, dan sebanyak $38 \%$ responden yang berperilaku konsumsi obat yang kurang baik.
Perilaku seseorang adalah proses atau aktivitas individu yang melibatkan pencarian, penyeleksian, pembelian, penggunaan, dan pengevaluasian atas produk dan jasa untuk memenuhi kebutuhan, mendapat dorongan-dorongan untuk mencari informasi mengenai produk-produk yang dapat memuaskan dan dapat memenuhi kebutuhan, ketika konsumen mendapatkan dan menggunakan informasi yang berasal dari sumber eksternal (Wulandari, 2014).

\section{f. Validitas dan Reabilitas}

Untuk melihat pengaruh iklan obat di media terhadap perilaku konsumsi obat pada masyarakat dengan menggunakan kuisioner, sebelum digunakan pada saat penelitian, kuisioner menggunakan sistem komputersasi dengan cara uji validitas yang digunakan adalah realiabilitas

\section{PEMBAHASAN}

Pengaruh iklan obat di media terhadap perilaku konsumsi obat

Berdasarkan penelitian yang dilakukan pada 100 responden di kelurahan tanah patah, dari 76 responden $(76 \%)$ yang terpengaruh pada iklan obat, terdapat 22 responden 
$(28,9 \%)$ dengan perilaku konsumsi obat yang baik, 24 responden $(31,6 \%)$ yang terpengaruh pada iklan obat dengan perilaku konsumsi obat yang cukup baik, dan 30 responden $(39,5 \%)$ yang terpengaruh pada iklan obat dengan perilaku konsumsi obat yang kurang baik.

Perilaku konsumsi obat seseorang dipengaruhi oleh pengetahuan dan kemauan untuk mengenal penyakit yang di deritanya Pengetahuan yang kurang tentang tentang pengobatan pada penyakit yang di deritanya mempengaruhi seseorang dalam berperilaku untuk mengkonsumsi obat dimana jika seseorang dengan pengetahuan dan kemauan yang kurang tentang pengobatan pada penyakit, maka perilaku konsumsi obatnya kurang baik, begitupun sebaliknya jika seseorang mempunyai pengetahuan dan kemauan yang baik maka perilaku konsumsi obatnya baik (Notoatmojo, 2009).

Tujuan pengobatan sendiri adalah untuk peningkatan, pengobatan sakit ringan, dan pengobatan rutin penyakit kronis setelah perawatan dokter. Sementara itu, peran pengobatan sendiri adalah untuk menanggulangi secara cepat dan efektif keluhan yang tidak memerlukan konsultasi medis, mengurangi beban pelayanan kesehatan pada keterbatasan sumber daya dan tenaga, serta meningkatkan keterjangkauan masyarakat yang jauh dari pelayanan kesehatan (Riswaka, 2011).

Perilaku pengobatan sendiri menggunakan obat bebas dan bebas terbatas merupakan salah satu perilaku kesehatan. Banyak faktor yang berhubungan dengan perilaku penggunaan obat dalam pengobatan sendiri. Belum diketahui faktor yang paling berpengaruh dalam perilaku pengobatan sendiri, namun demikian faktor yang paling berpengaruh dalam perilaku pengobatan sendiri adalah tingkat pendidikan. Semakin tinggi pendidikan, pengobatan yang dilakukan juga semakin baik (Supardi, 2012).

Sedangkan dari 24 responden (24\%) yang tidak terpengaruh pada iklan obat, terdapat 15 responden $(62,5 \%)$ dengan perilaku konsumsi obat yang baik, 1 responden $(4,2 \%)$ yang tidak terpengaruh pada iklan obat dengan perilaku konsumsi obat yang cukup baik, dan 8 responden $(33,3 \%)$ yang tidak terpengaruh pada iklan obat dengan perilaku konsumsi obat yang 
kurang baik.

Bila digunakan secara benar, obat bebas dan obat bebas terbatas seharusnya bisa sangat membantu masyarakat dalam pengobatan sendiri secara aman dan efektif. Namun sayangnya, seringkali dijumpai bahwa pengobatan sendiri menjadi sangat boros karena mengkonsumsi obat-obat yang sebenarnya tidak dibutuhkan, atau malah bisa berbahaya misalnya karena penggunaan yang tidak sesuai dengan aturan pakai. Bagaimanapun, obat bebas dan bebas terbatas bukan berarti bebas efek samping, sehingga pemakaiannya pun harus sesuai dengan indikasi, lama pemakaian yang benar, disetrai dengan pengetahuan pengguna tentang resiko efek samping dan kontraindikasinya (Supardi, 2012).

Faktor-faktor yang berpengaruh dalam pemberian obat kurang baik antara lain, kurangnya pengetahuan dari tenaga kesehatan dalam ilmu obat-obatan adanya kebiasaan dokter meresepkan jenis atau merk obat tertentu kepercayaan masyarakat terhadap jenis atau merk obat tertentu keinginan pasien yang cenderung ingin menggunakan obat tertentu, dengan sugesti menjadi lebih cepat sembuh adanya sponsor dari industri farmasi tertentu pemberian obat berdasarkan adanya hubungan baik perorangan dengan pihak dari industri farmasi adanya keharusan dari atasan dalam suatu instansi atau lembaga kesehatan untuk meresepkan jenis obat tertentu informasi yang tidak tepat (Supardi, 2012).

Sehingga pemakaian obat menjadi tidak tepat beban pekerjaan yang terlalu berat sehingga tenaga kesehatan menjadi tidak sempat untuk berpikir mengenai baik pemakaian obat dan adanya keterbatasan penyediaan jenis obat di suatu instansi atau lembaga kesehatan tertentu, sehingga jenis obat yang diperlukan untuk suatu penyakit justru tidak tersedia, sehingga memakai obat yang lain (Supardi, 2012).

Adanya berbagai media informasi (media cetak, televisi, radio, internet, dst) juga memberikan efek kurang baik yang menyebabkan masyarakat menggampangkan memakai obat seperti obat pengurang nyeri atau penurun panas yang tidak tepat indikasi pemakaiannya. Seperti karena adanya beban pekerjaan, maka seseorang dengan gampang menggunakan obat pengurang nyeri karena merasa sedikit nyeri kepala. Begitupun bagi para ibu rumah tangga yang cepat merasa khawatir apabila 
ada anaknya yang demam, maka dengan cepat mereka diberikan obat penurun panas (Riswaka, 2011).

Hasil penelitian ini berhasil membuktikan hipotesa yaitu ada pengaruh iklan obat di media terhadap perilaku konsumsi obat dimasyarakat Kelurahan Tanah Patah Kota Bengkulu, dibuktikan dengan menggunakan uji Chi-Square. Hasil uji Chi-Square didapat nilai $\mathrm{p}=$ 0,004 . Karena nilai $p<0,05$ berarti bermakna Ho ditolak dan Ha diterima artinya ada pengaruh iklan obat di media terhadap perilaku konsumsi obat dimasyarakat Kelurahan Tanah Patah Kota Bengkulu.

Iklan memiliki fungsi menyampaikan informasi, membujuk atau untuk mengingatkan masyarakat terhadap produk obat sehingga masyarakat terpengaruh adanya iklan obat dimedia dan hasil penelitian ini membuktikan ada pengaruh iklan terhadap perilaku konsumsi pada masyarakat, pada penelitian ini wanita yang mudah terpengaruh dengan iklan obat dimedia (Kurniawan, 2010).

\section{DAFTAR PUSTAKA}

Hilman, 2011, Perilaku Pengobatan Sendiri di Masyarakat, diakses pada 19 Oktober 2015, http://www.scribd.com

Kurniawan W, 2010, Pelayanan Informasi Obat, Graha Ilmu. Yogyakarta

Notoatmojo, Soekidjo, 2007, Pendidikan dan Perilaku Kesehatan, Rineka Cipta. Jakarta

Notosiswoyo S,S, 2011, Pengobatan Sendiri di Masyarakat dan Masalahnya. Pusat Penelitian dan pengembangan Farmasi Badan Penelitian dan Pengembangan Kesehatan Departemen Kesehatan RI, Jakarta,

Riswaka, 2007, Cara penggunaan obat tepat, aturan pakai obat Rineka Cipta. Jakarta
Sarwono S, 2004 . Sosiologi Kesehatan, Yogyakarta Gadjahmada University

Sudigdo, S, 2008. Dasar-dasar Metodologi Penelitian Klinis, Edisi 3. Sagung Sento Jakarta:

Supardi, 2007. Pengobatan sendiri, obat bebas, obat bebas terbatas, Salemba Medika. Jakarta

Widyatama, 2007. Komunikasih dalam iklan dan penyampaian pesan, Semarang cipta, Semarang

Wulandari, 2010. Aktivitas individu dan Perilaku manusia, Rineka Cipta. Jakarta 


\title{
Lampiran : Pedoman Penulisan Jurnal Ilmiah Pharmacy
}

\section{INFORMASI UNTUK PENULIS}

Jurnal Ilmiah Pharmacy menerima tulisan ilmiah berupa laporan hasil penelitian di bidang ilmu Farmasi, Kedokteran, Kimia, Biologi, Fisika, Kebidanan, Keperawatan , Kesehatan Masyarakat, Gizi dengan frekuensi terbit 2 kali setahun (Maret dan Oktober).

Naskah yang diajukan adalah naskah yang belum pernah diterbitkan di media lain, baik cetak maupun elektronik. Jika sudah pernah disajikan dalam suatu pertemuan ilmiah hendaknya diberi keterangan yang jelas mengenai nama, tempat, dan tanggal berlangsungnya pertemuan tersebut.

Naskah ditulis dalam bahasa Indonesia baku atau Bahasa Inggris dengan huruf Times New Roman (TNR), disusun dengan sistematika sebagaimana yang disarankan di bawah ini.

Sistematika penulisan judul, penulis dan abstrak:

○ Judul :

Judul penelitian bersifat informative, singkat dan jelas mencerminkan isi tulisan dan tidak melebihi $18 \mathrm{kata}$, ditulis dalam bahasa Indonesia dengan UPPERCASE (Huruf besar semua terkecuali nama ilmiah menggunakan Title Case), Font TNR 14, Bold, 1 spasi, Center (pyramid terbalik).

Contoh :

\section{UJI EFEKTIVITAS ANTIHIPERGLIKEMIA AIR REBUSAN KULIT BUAH JENGKOL (Pithecellobium jiringa (Jack) Prain) PADA MENCIT PUTIH JANTAN YANG DIINDUKSI SUKROSA}

\section{- Nama dan Lembaga Penulis}

Masing-masing nama penulis ditulis dengan lengkap tanpa gelar dan diakhiri dengan nomor superscript (jika semua penulis tidak berasal dari institusi yang sama), diikuti dengan afiliasi/institusi masing-masing dan alamat korespondensi penulis utama yang dilengkapi dengan alamat surat elektronik (email), Font TNR 12, Bold, Center, 1 spasi. Jarak antara nama dengan lembaga penulis yaitu enter 2 spasi

\section{Contoh :}

\author{
Ananda Rahayu Mardia ${ }^{1}$, Sindiana Sari², Cahaya Romadon ${ }^{2}$ \\ ${ }^{1}$ Akademi Farmasi Al-Fatah Bengkulu \\ ${ }^{2}$ Universitas Terbuka Bengkulu \\ E-mail : anandarahayumardia@gmail.com
}

- Abstrak

Ditulis dalam bahasa Indonesia, maksimum 200 kata dengan ukuran huruf TNR 12, 1 spasi, memuat komponen latar belakang, tujuan, metode, hasil dan kesimpulan. dilengkapi dengan kata kunci dengan jumlah 3-5 kata, Bold.

Sistematika penulisan isi dan kepustakaan: 
- Isi tulisan disusun dengan sistematika: Pendahuluan, Metode Penelitian (meliputi Tempat dan Waktu Penelitian, Alat dan Bahan Penelitian, Prosedur Penelitian, Analisa Data); Hasil dan Pembahasan, Kesimpulan dan Saran, Ucapan Terima Kasih (jika diperlukan), Daftar Pustaka. Penulisan : UPPERCASE (Huruf besar semua) dan untuk Sub Judul : Title Case (Huruf besar pada huruf awal setiap kata selanjutnya hurup kecil semua terkecuali kata penghubung),Font TNR 12, Bold. Semua tulisan dibuat dengan spasi 1,5 TNR 12.

\section{PENDAHULUAN}

Pendahuluan memuat latar belakang penelitian dilakukan untuk menjawab keingintahuan peneliti dalam mengunggkapkan gejala/konsep/dugaan atau menerangkan pada satu tujuan, memberikan argument pentingnya penelitian dilakukan. Setiap paragraph harus disertakan catatan kaki (Rujukan kepustakaan dilakukan dengan sistem nama dan tahun. Contoh : (Atmajaya. N, 2016).

\section{METODE PENELITIAN}

Metode penelitian menguraikan tentang Tempat dan Waktu Penelitian, Alat dan Bahan Penelitian, Prosedur Penelitian dan Analisa Data.

\section{HASIL DAN PEMBAHASAN}

Hasil penelitian menguraikan hasil yang diperoleh dari penelitian yang dilakukan kemudian dibuat pembahasannya berdasarkan analisa dan perbandingan data yang telah ada.

\section{KESIMPULAN DAN SARAN}

Berisi kesimpulan berupa jawaban atas permasalahan dalam penelitian. Saran, berisi saran untuk langkah penulis selanjutnya yang mengacu manfaat penelitian (bila ada)

UCAPAN TERIMA KASIH (jika diperlukan bila mendapatkan dana hibah)

\section{DAFTAR PUSTAKA}

Daftar pustaka hendaknya mengacu kepada sumber pustaka 10 tahun terakhir. Daftar pustaka ditulis berurutan berdasarkan alfabetis dan ditulis secara konsisten menurut ketentuan APA (American Psychological Association) Citation Style, Spasi 1 berdasarkan alfabetis dengan contoh sebagai berikut :

Kesehatan, M., Volume, F., \& Sgot, K. 2015. Effect of Propolis Extract on SGOT (Serum Glutamic Oxaloacetic Transaminase) and SGPT (Serum Glutamic Pyruvic Transaminase) Level of Wistar Rats ( Rattus norvegicus ) with High Fat Diet, 2(September), 120-126.

\section{Teknik penulisan isi, tabel, dan gambar:}

- Naskah dibuat pada dokumen Microsoft Office Word dengan format DOC; diketik 1,5 spasi terkecuali judul, superscript, abstrak dan daftar pustaka 1 spasi,

- Format paper berukuran A4 $(210 \times 297 \mathrm{~mm})$ dengan margin kiri $4 \mathrm{~cm}$, atas $3 \mathrm{~cm}$, kanan 2.5 $\mathrm{cm}$, bawah $2.5 \mathrm{~cm}$, dengan jumlah halaman 8-10 halaman.

- Tabel harus utuh, jelas terbaca, diberi judul dengan nomor urut tabel berupa angka (Tabel 1, 2, 3 dan seterusnya, bold, Center, 1 spasi, 10 font TNR).

- Gambar dibuat dengan format JPG/JPEG atau PNG, diberi keterangan pada bagian bawahnya dengan nomor urut gambar berupa angka (Gambar 1, 2, 3 dan seterusnya, bold, Center, 1 spasi, 10 font).).

Naskah dikirim dalam bentuk berkas elektronik ke alamat email : 
Ippmakfar_alfatah13@yahoo.com atau Open Jurnal System http ://jurnal.akfar-alfatah.ac.id dapatmengikuti panduan yang tersedia pada website. Format pengiriman email :

Judul email : "[Submission] - empat kata pertama dari judul tulisan - nama penulis",

contoh: [Submission] - Evaluasi Penggunaan Antibiotik Fluoroquinolon - Densi Selpia

Isi email : Harus mencantumkan nama dan afiliasi/asal institusi pengirim beserta judul artikel yang diajukan.

Attachment (lampiran) email: artikel berupa dokumen Microsoft Office Word 97-2003 (format DOC) yang diberi nama "[nama penulis]-[empat kata pertama dari judul tulisan] - JIP", contoh: Densi Selpia-Evaluasi Penggunaan Antibiotic Fluoroquinolon-JIP

Naskah yang masuk ke meja redaksi akan disaring oleh editor, kemudian direview. Apabila diperlukan, naskah akan diberi catatan dan dikembalikan kepada penulis untuk direvisi, untuk selanjutnya dikirimkan kembali secara utuh kepada redaksi untuk diterbitkan.

Setiap artikel yang dinyatakan diterima untuk diterbitkan dikenakan biaya penerbitan sebesar Rp Rp. 200.000,00- (Dua Ratus Ribu Rupiah per Eksemplarnya) dimana penulis akan menerima 1 eksemplar jurnal pada nomor tersebut. Penambahan eksemplar akan dikenakan biaya yang sama per eksemplarnya. Biaya tersebut dapat ditransfer ke rekening AKADEMI FARMASI ALFATAH BENGKULU di Bank Syariah Mandiri Cabang : KC Bengkulu No. Reg 7080825597 setelah artikel dinyatakan diterima untuk diterbitkan dan setelah dilakukan revisi sesuai ketentuan.

\section{Ka. P3M AKFAR AF}

Ttd

\section{Devi Novia, M.Farm.,Apt}

NIDN. 0214128501

$C t t$ :

Apabila terdapat kekeliruan akan diperbaiki dan diberitahukan secara langsung kepada penulis. 


\section{Jurnal Ilmiah Pharmacy \\ Akademi Farmasi Al-Fatah Bengkulu \\ Jln. Indragiri Gang 3 Serangkai Padang Harapan Bengkulu \\ Telp/fax : 0736-27508. \\ Web : http://jurnal.akfar-alfatah.ac.id/lwww.akfar-alfatah.ac.id / \\ www.pppm.akfar-alfatah.ac.id \\ email : info@akfar.ac.id/lppmakfar_alfatah13@yahoo.com}

\section{CHECK LIST PANDUAN PENULISAN}

\section{Judul Naskah}

Penulis

\begin{tabular}{|c|l|l|}
\hline 1. & $\begin{array}{l}\text { Naskah dibuat pada paper berukuran A4 (210 x } 297 \mathrm{~mm}) \text { margin 4-3-2,5-2,5 } \\
\text { (kiri-atas-kanan-bawah) }\end{array}$ & \\
\hline 2. & Judul tidak lebih dari 18 kata Times New Roman ukuran 14, Bold Center, 1 spasi & \\
\hline 3. & $\begin{array}{l}\text { Nama penulis Font TNR 12, Bold, Center, 1 spasi, dilengkapi dengan } \\
\text { afiliasi/institusi asal }\end{array}$ & \\
\hline 4. & Semua penulis dilengkapi dengan alamat email & \\
\hline 5. & Abstrak tidak lebih dari 200 kata & \\
\hline 6. & Abstrak dilengkapi dengan masing-masing 3-5 kata kunci dan keywords & \\
\hline 7. & Isi naskah diketik dengan huruf Times New Roman ukuran 12 dengan spasi 1,5 & \\
\hline 8. & $\begin{array}{l}\text { Sistematika isi : PENDAHULUAN, METODE PENELITIAN, HASIL dan } \\
\text { PEMBAHASAN, KESIMPULAN dan SARAN }\end{array}$ & \\
\hline 9. & \begin{tabular}{l} 
Sitasi (catatan kaki) di dalam naskah dibuat dengan sistem (nama pengarang, \\
\hline 10.
\end{tabular} & Daftar Pustaka ditulis menurut APA Style \\
\hline 11. & Daftar Pustaka diurut berdasarkan alfabetis \\
\hline 12. & Naskah dibuat dalam dokumen dengan format .doc atau bukan .docx & \\
\hline
\end{tabular}

Biaya penerbitan sebesar Rp. 200.000,00- (Dua Ratus Ribu Rupiah per Eksemplarnya) dapat ditransfer ke rekening AKADEMI FARMASI ALFATAH BENGKULU di Bank Syariah Mandiri Cabang : KC Bengkulu No. Reg 7080825597 setelah artikel dinyatakan diterima untuk diterbitkan dan setelah dilakukan revisi sesuai ketentuan

\section{Catatan:}

$\checkmark \quad$ : Jika sudah sesuai format $\quad X \quad$ : Jika belum sesuai format Penulisan daftar pustaka harap mengikuti kaidah APA Style sesuai contoh berikut:

Kesehatan, M., Volume, F., \& Sgot, K. (2015). Effect of Propolis Extract on SGOT (Serum Glutamic

Oxaloacetic Transaminase) and SGPT (Serum Glutamic Pyruvic Transaminase) Level of Wistar Rats

( Rattus norvegicus ) with High Fat Diet, 2(September), 120-126. 
Lampiran : Balasan Bila Jurnal Sudah Disetujui

\section{$\underline{\text { LETTER OF ACCEPTANCE (LoA) }}$}

\section{Kepada Yth Bpk/Ibu/Sdr}

Di

Tempat

Dengan ini kami sampaikan bahwa artikel dengan rincian berikut dinyatakan

diterima untuk diterbitkan di dalam Jurnal Ilmiah Pharmacy Akademi Farmasi Al-Fatah Bengkulu, Volume (...) Nomor (...) (Bulan Tahun Terbit)

Judul :
Penulis :
*Email :

Demikianlah surat keterangan ini kami buat untuk dapat digunakan seperlunya.

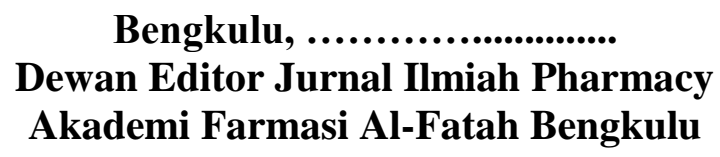

Ka. P3M AKFAR AF

Editor P3M AKFAR AF 